\title{
Analysing the Systemic Risk of Indian Banks
}

\begin{abstract}
This paper adopts the TENET - Tail Event Driven Network modeling structure to assess the systemic risk of Indian banks. Building upon the Value at Risk (VaR), Conditional Value at Risk (CoVaR) and a Single Index Model (SIM) in a generalized quantile regression framework, the results suggest that the interconnectedness among Indian banks intensifies during the crisis period. These results open a new avenue to explore the deeper cracks in the Indian banking system.
\end{abstract}

JEL Classifications: G01, G18, G32, C21, C51, C63

Keywords: Systemic Risk Network, Government Policy and Regulation, Financial Policy, Quantile Regression, Value at Risk, CoVaR, Indian Banks 


\section{Introduction}

Indian economy is currently experiencing an unprecedented level of systemic risk in its banking system. The genesis of this crisis is often linked with the mid-2000s investment boom when the Indian government announced major infrastructure investment plans related to power generation, steel, and telecom sectors to augment the growth process. The Economic Survey (2016-2017) also linked it with the Twin Balance Sheet (hereafter TBS) syndrome under which worsening profit and consequent default on corporate loans impaired the balance sheet of lending banks. In a comprehensive policy exercise, in 2015, the Reserve Bank of India (henceforth, RBI) conducted an Asset Quality Review (AQR) under which banks were directed to clear the debris of bad corporate debt and to report the number of loans accounts which may turn sooner or later into non-performing assets (NPAs). From research perspective, the crisis has opened a flood gate to examine the Indian banks from various dimensions including the assessment of systemic risk.

In this study, we aim to measure the strength of interconnectedness among government and privately owned banks to understand the riskiness of the Indian banking system. To do this, we apply the methodology of Tail-Event-Driven Networks (TENET) proposed by Härdle et al. (2016). We use the model for two reasons: Firstly, it helps to calculate the riskiness of Indian banking system under an ultra high-dimensional set-up which allows incorporating not only the macroeconomic variables but also the balance sheet variables in systemic risk analysis. Second, the magnitude of directional connectedness helps us identify the major systemic risk receiver (SRR) and systemic risk emitter (SRE) banks. By taking into account 
the period of release of the AQR report and Bank of Baroda as an anecdotal event, this study is the first systemic attempt to study the systemic risk in the Indian context. ${ }^{1}$

The notable studies in the field of systemic risk can be divided into three generations: the first generation focusses upon the factor approach based correlations of financial assets across financial institutions to calculate their default probabilities (Huang et al., 2009; Zhou, 2010; Kritzman et al., 2011; Billio et al., 2012; Patro et al., 2013). The second generation focusses upon tail dependence across financial institutions at different risk levels (Zhou, 2010; Acharya et al., 2012; Banulescu and Dumitrescu, 2015; Adrian and Brunnermeier, 2016; Acharya et al., 2017; Brownlees and Engle, 2017). The third generation covers the systemic risk using network models to analyse the interconnectedness across financial institutions by inferring upon the magnitudes of nodes and edges (Billio et al., 2012; Diebold and Y1lmaz, 2014; Levy-Carciente et al., 2015; Battiston et al., 2016; Härdle et al., 2016; Wang et al., 2018).

The rest of the paper is organized as follows. In section 2, we explain the data and TENET model specification. Section 3 discusses the results and application of TENET model. Section 4 concludes.

\section{Data and methodology}

In this study, we use weekly data that covers the period from 12 January 2007 to 31 March 2017 on 31 Indian Banks, out of which 20 are government-owned banks and 11 are private banks. The banks considered in our study are listed in Table (1) along with their abbreviations and the descriptive statistics for the returns of these banks over the sample period. The sample series are retrieved from Thomson DataStream and Reserve Bank of India

\footnotetext{
${ }^{1}$ We consider Bank of Baroda (hereafter, BOB) because after the promulgation of AQR report by RBI, BOB has reported the maximum loss (Economic Survey, 2016-2017). For TENET analysis, we have identified February 2016.
} 
(RBI). Following Härdle et al. (2016) and Wang et al. (2018), we include the balance sheet variables, which include leverage, size, market to book ratio, debt to maturity, return on assets (ROA). Keeping in mind the liquidity and risk coverage dimension, we consider shortterm liquidity spread, immediate period changes in the 90-day treasury bill rate, spread between ten-year and three-month treasury bill rate, credit spread, stock market returns, market volatility, lending rate and weekly equity returns of each sample bank. The sample variables are outlined in online appendix Table (A1) along with their description and sources.

Following Härdle et al. (2016), we adopt three steps empirical procedure to perform TENET analysis of Indian banks. At first step, we calculate the Value at Risk (VaR) and CoVaR (Conditional Value at Risk) of sample banks at 0.01 and 0.05 quantiles to capture the tail event and also to test the robustness of results. We calculate $\mathrm{VaR}$ of each bank $i$ at given $\tau \in(0,1)$ at time $t$ as: $P\left(B_{i, t} \leq \operatorname{VaR}_{i, t, \tau}\right)=\tau$, where $\tau$ is the quantile level, $B_{i, t}$ shows the $\log$ returns of bank $i$ at time $t$. The CoVaR of a sample bank $j$ given $B_{i, t}$ at given level $\tau \in(0,1)$ is defined as $P\left(B_{j, t} \leq \operatorname{VaR}_{j \mid t, \tau} \mid R_{i, t}\right)=\tau$, where $R_{i, t}$ denotes the information set which includes the events of $B_{i, t}=\operatorname{VaR}_{i, t, \tau}$ and $M_{t-1} \cdot M_{t-1}$ includes the vector of macroeconomic variables. Following Härdle et al. (2016), our specification of CoVaR follows two-step linear quantile regression (hereafter, LQR) procedure:

$$
\begin{aligned}
& B_{i, t}=\alpha_{i}+\beta_{i} M_{t-1}+\varepsilon_{i, t} \\
& B_{j, t}=\alpha_{j \mid t}+\gamma_{j \mid i} M_{t-1}+\beta_{j \mid i} B_{j, t}+\varepsilon_{j \mid i, t}
\end{aligned}
$$

We then apply the quantile regression of return of a bank $i$ on the macro variables to determine the $\operatorname{VaR}$ of a bank $i . \beta_{j i}$ shows the extent of sensitivity of a bank $j$ to changes in 
tail event log return of a bank $i$. Similarly, the CoVaR is obtained by plugging in VaR of bank $i$ at level $\tau$ estimated in equation (3) into the equation (4):

$\operatorname{VaR}_{i, t, \tau}=\alpha_{i}+\beta_{i} M_{t-1}$

$\operatorname{CoVaR}_{j \mid i, t, \tau}=\alpha_{j \mid t}+\hat{\gamma}_{j \mid i} M_{t-1}+\beta_{j \mid i} \operatorname{VaR}_{i, t, \tau}$

At the second step, we adopt a single index model (SIM) for generalized quantile regressions to find the systemic risk contribution of each banks in our sample conditional on its tail interconnectedness with relevant banks. The step builds the systemic risk network by applying the directional spillover approach given by Diebold and Yilmaz (2014) as follows:

$B_{j, t}=f\left(\beta_{j \mid R_{j}}^{\mathrm{T}} R_{j, t}\right)+\varepsilon_{j, t}$

$\operatorname{CoVaR}_{j \mid \bar{R}_{j}, t, \tau}=\hat{f}\left(\beta_{j \mid \tilde{R}_{j}}^{\mathrm{T}} \tilde{R}_{j, t}\right)$

$D_{j \mid \tilde{\mathbb{R}}_{j}}=\left.\frac{\partial \hat{f}\left(\beta_{j \mid R_{j}}^{\mathrm{T}} R_{j, t}\right)}{\partial R_{j, t}}\right|_{\mathbb{R}_{j, t}=\tilde{R}_{j, t}}=\partial \hat{f}\left(\beta_{j \mid \tilde{R}_{j}}^{\mathrm{T}} \tilde{R}_{j, t}\right) \beta_{j \mid \tilde{R}_{j}}$

where $R_{j, t}=\left\{X_{-j t}, M_{t-1}, S_{j, t-1}\right\}$ is the information set which includes $k$ variables. $X_{-j t}=\left\{X_{1 t}, X_{2 t}, \ldots, X_{m, t}\right\}$ are the explanatory variables, which include the returns of all the sample banks except for Bank of Baroda (BOB) $j . m$ shows the number of banks. $S_{j, t-1}$ is the bank-specific characteristics indicators calculated from their balance sheet. We define the parameters as $\beta_{j \mid R_{j}}=\left\{\beta_{j \mid-j}, \beta_{j \mid M}, \beta_{j \mid s_{j}}\right\}^{\mathrm{T}}$ which are static. To get the time-varying estimates, we use the rolling window estimation to estimate all coefficients. $D_{j \mid \tilde{\mathbb{R}}_{j}}$ shows the gradient that measures the marginal effect of covariates evaluated at $R_{j, t}=\tilde{R}_{j, t}$ and the component-wise 
expression is $D_{j \mid \tilde{\mathrm{R}}_{j}}=\left\{D_{j \mid-j}, D_{j \mid M}, D_{j \mid S_{j}}\right\}^{\mathrm{T}} . D_{j \mid-j}$ shows the spillover effects across sample banks and also to characterize their networks. It is again noteworthy that the network charts exhibit the partial derivatives of banks $j$ with respect to other banks i.e. $D_{j-j}$ and do not include $D_{j \mid S_{j}}$ and macroeconomic variables $D_{j \mid M}$.

In the third step, we identify the S-DIBs based on SRR and SRE measures. The SRR for a bank $j$ therefore defined as:

$$
S R R_{j, s}=M C_{j, s}\left\{\sum_{i \in k_{s}^{I N}}\left(\left|\tilde{D}_{j \mid i}^{s}\right| \cdot M C_{i, s}\right)\right\}
$$

The SRE for a bank $j$ is defined as

$$
S R E_{j, s}=M C_{j, s}\left\{\sum_{i \in k_{s}^{\text {OUT }}}\left(\left|\tilde{D}_{i \mid j}^{s}\right| \cdot M C_{i, s}\right)\right\}
$$

where $k_{s}^{I N}$ and $k_{s}^{\text {OUT }}$ are the set of banks connected with bank $j$ (BOB) by incoming and outgoing networks at window $s$, respectively. $M C_{i, s}$ represents the market capitalization of bank $i$ at the starting point of window $s .\left|\tilde{D}_{j \mid i}^{s}\right|$ and $\left|\tilde{D}_{i \mid j}^{s}\right|$ are absolute partial derivatives which represent row (incoming) and column (outgoing) directional connectedness of bank $j$ to $i$.

\section{Results}

Fig. (1) shows the estimated VaR (red line) and CoVaR of BOB estimated by applying linear and SIM models (green and blue lines). The two measures (VaRs and CoVaRs) at 0.01 and 0.05 quantiles exhibit high variations during 2008-2009, a period marked as a global financial crisis (GFC, 2008). Without reporting the results of total and directional connectedness, we analyze the connectedness of Indian banks with incoming and outgoing links at 0.05 and 0.01 
quantiles shown in figs $(2$, panels $A \& B) .{ }^{2}$ We divide our sample of Indian banks into two groups: government-owned banks (GOBs) and private-owned banks (POBs). Using the rolling window of 50 weeks (534 observations), the results indicate that the GOBs appear to be more sensitive during crisis and slowdown phases as compared to POBs. The figures also capture the major crisis events such as the GFC and the periods of the subdued performance of Indian banks reported by the Financial Stability Report (FSR, December 2015) of RBI. The FSR (2015) revealed the issues of reforms and recapitalization of Indian banks and balance sheet slowdown. ${ }^{3}$ The steep rise in the incoming and outgoing links of both the groups exhibit the strong connection, suggesting the possible impact of post-TBS crisis and the enactment of IBC.

Fig. (3) shows the bank level interconnectedness using networks: $D C_{j \mid i}^{s}=\left|\hat{D}_{j \mid i}^{s}\right|$. The node shows the size of the bank represented by market capitalization and edge shows the strength of pairwise connections. We find that at 0.05 quantile, $\mathrm{OBC}$ appears to be strongly connected to UBI and ALLA. And at 0.01 quantile, two pairs (ALLA to ANDB) and (OBC to UBI) exhibit strong relationship. Overall, we find that OBC appears to be the common at both quantiles exhibiting the strong interbank connectedness. It may need further investigation at micro level.

We also find that the mid-size banks appear to have strong bilateral connections than the large banks. GOBs exhibit directional connectedness with POBs. For instance, HDFC, ICICI, AXIS, FEDB and YES banks exhibit limited interdependence except for DCB. We also rank the banks based on the magnitude of outgoing (To) and incoming (From) links shown in online appendix tables (A2 \& A3). We find that the most connected bank with incoming link is UBI followed by IOB and OBC. The most connected bank with the outgoing

\footnotetext{
${ }^{2}$ The detailed results are available upon request.

${ }^{3}$ See for details: https://rbi.org.in/Scripts/FsReports.aspx (accessed on 22 April 2018).
} 
link is OBC followed by UBI and DCB. These results suggest that the most risk emitting bank seems to be OBC followed by ALLA.

We also calculate the exact systemic risk measure for each bank based on their extent of connectedness using equations $(8 \& 9)$. We do this by considering the market capitalization of each bank and its connected banks with incoming and outgoing links. Tables (2\&3) show the ranking of the top 10 calculated SRRs and SREs at 0.05 and 0.01 quantiles, respectively. At 0.05 quantile, top three SRRs and SREs are SBI, HDFC \& CNRB and PNB, YES \& AXIS, respectively. At 0.01 quantile, top three SRR and SRE are the same: HDFC, ICICI, and AXIS. The striking finding is that the rankings confirm the RBI's classification of DSIBs. Since August 2015, RBI has been publishing the list of D-SIBs as part of its Financial Stability Report. As of April 2016, the D-SIB included SBI, ICICI and HDFC banks. ${ }^{4}$ Out of these three, two banks (SBI and HDFC) appeared in our list of SRR rankings. Similarly, at 0.01 quantile, we find HDFC and ICICI as the major SRE banks.

\section{Conclusion}

In this paper, we assess the systemic risk of the crisis-ridden Indian banking sector using the novel methodology. The analysis almost explains the different facets of inter-bank connectedness. The key takes away is that the model helps identify the major risk receiving and emitting banks. The model also helps identify the D-SIBs which agree with the rankings of RBI. We finally recommend the formal adoption of TENET model in systemic risk analysis.

\section{References}

Acharya, V. V., Pedersen, L. H., Philippon, T., \& Richardson, M. (2017). Measuring system risk. The Review of Financial Studies, 30(1), 2-47.

\footnotetext{
${ }^{4}$ For more details, please refer: https://rbi.org.in/Scripts/BS_PressReleaseDisplay.aspx?prid=41556 (accessed on 24 April 2018).
} 
Acharya, V., Engle, R., \& Richardson, M. (2012). Capital shortfall: A new approach to ranking and regulating systemic risks. American Economic Review, 102(3), 59-64.

Adrian, T., \& Brunnermeier, M. K. (2016). CoVaR. American Economic Review, 106(7), 1705-41.

Banulescu, G.-D., \& Dumitrescu, E.-I. (2015). Which are the SIFIs? A Component Expected Shortfall approach to systemic risk. Journal of Banking \& Finance, 50, 575-588.

Battiston, S., Gatti, D. D., Gallegati, M., Greenwald, B., \& Stiglitz, J. E. (2012). Liaisons dangereuses: Increasing connectivity, risk sharing, and systemic risk. Journal of Economic Dynamics and Control,, 36(8), 1121-1141.

Billio, M., Getmansky, M., Lo, A. W., \& Pelizzon, L. (2012). Econometric measures of connectedness and systemic risk in the finance and insurance sectors. Journal of Financial Economics, 104(3), 535-559.

Bisias, D., Flood, M., Lo, A. W., \& Valavanis, S. (2012). A Survey of Systemic Risk Analytics. Annual Review of Financial Economics, 4, 255-296.

Brownlees, C., \& Engle, R. F. (2016). SRISK: A conditional capital shortfall measure of systemic risk. The Review of Financial Studies, 30(1), 48-79.

Diebold, F. X., \& Y1lmaz, K. (2014). On the network topology of variance decompositions: Measuring the connectedness of financial firms. Journal of Econometrics, 182(1), 119-134.

Härdle, W. K., Wang, W., \& Yu, L. (2016). TENET: Tail-Event driven NETwork risk. Journal of Econometrics, 499-513.

Hautsch, N., Schaumburg, J., \& Schienle, M. (2014). Financial network systemic risk contributions. Review of Finance, 19(2), 685-738.

Hautsch, N., Schaumburg, J., \& Schienle, M. (2015). Financial Network Systemic Risk Contributions. Review of Finance, 19(2), 685-738.

Huang, X., Zhou, H., \& Zhu, H. (2009). A framework for assessing the systemic risk of major financial institutions. Journal of Banking \& Finance, 33(11), 2036-2049.

IMF. (2009). Global Financial Stability Report: Responding to the Financial Crisis and Measuring Systemic Risk. Washington DC: International Monetary Fund.

Kritzman, M., Li, Y., Page, S., \& Rigobon, R. (2011). Principal Components as a Measure of Systemic Risk. The Journal of Portfolio Management, 37(4), 112-126.

Levy-Carciente, S., Kenett, D. Y., Avakian, A., Stanley, H. E., \& Havlin, S. (2015). Dynamical macroprudential stress testing using network theory. Journal of Banking \& Finance, 59, 164-181.

Patro, D. K., Qi, M., \& Sun, X. (2013). A simple indicator of systemic risk. Journal of Financial Stability, 9(1), 105-116.

Financial Stability Report (2015). Report on Trend and Progress of Banking in India 2014-15 and Financial Stability Report December 2015. Mumbai, India: Reserve Bank of India (RBI).

Economic Survey (2016-2017). Economic Survey 2016-2017. New Delhi: Ministry of Finance, Govt. of India .

Wang, G. J., Xie, C., He, K., \& Stanley, H. E. (2017). Extreme risk spillover network: application to financial institutions. Quantitative Finance, 17(9), 1417-1433.

Wang, G.-J., Jiang, Z.-Q., Lin, M., Xie, C., \& Stanley, H. E. (2018). Interconnectedness and systemic risk of China's financial institutions. Emerging Markets Review, 35, 1-18.

Zhou, C. (2010). Are banks too big to fail? Measuring systemic importance of financial institutions. International Journal of Central Banking, 6(4), 205-250. 
Figure 1: Riskiness of Bank of Baroda (BOB)

Bank of Baroda [0.05 quantile]

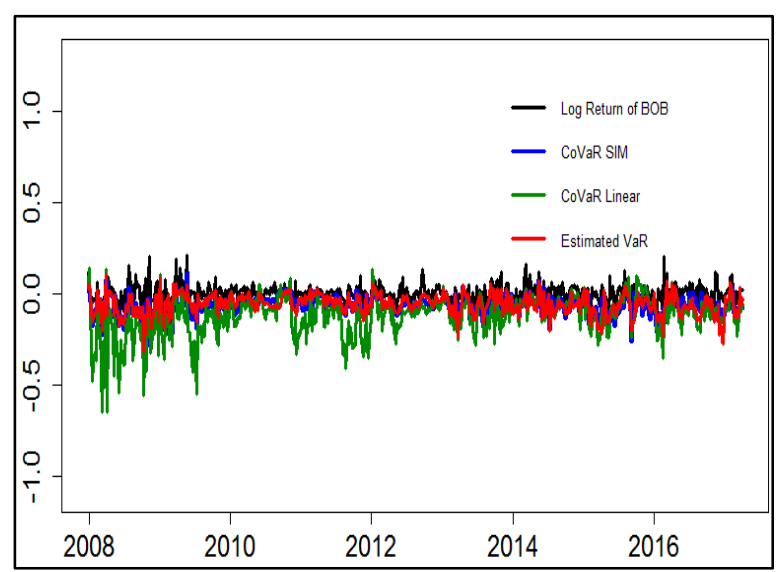

Bank of Baroda [0.01 quantile]

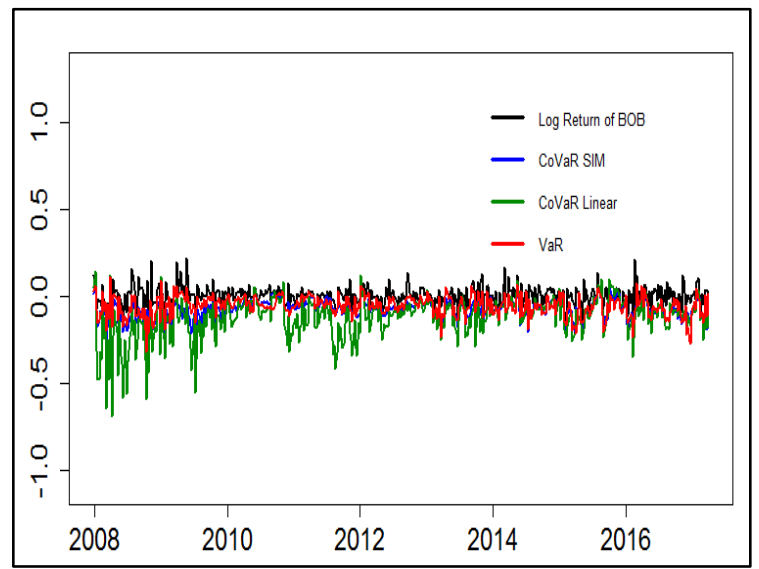

Notes: This figure shows the log returns of Bank of Baroda (BOB). The conditional risk measures (VaR, CoVaR SIM and CoVaR Linear) of BoB exhibit the clustering effect during 2008-2009, a period marked as global financial crisis period.

Figure 2: Total connectedness and Lambda

[0.05 quantile]

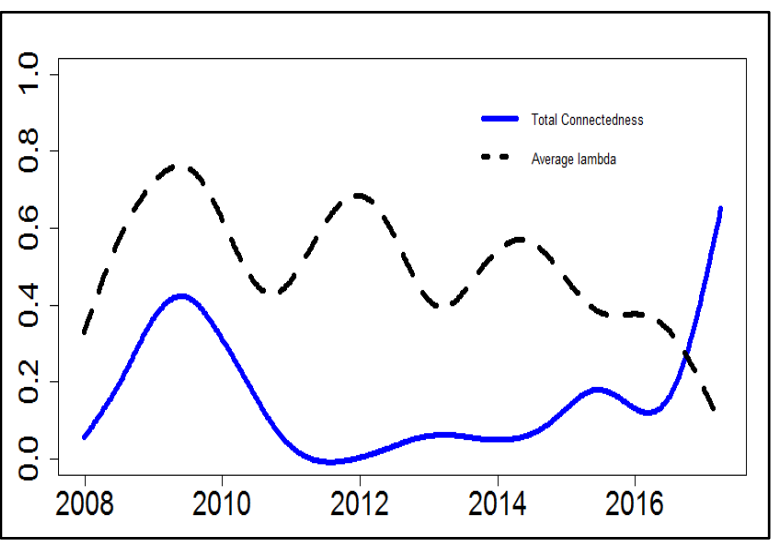

[0.01 quantile]

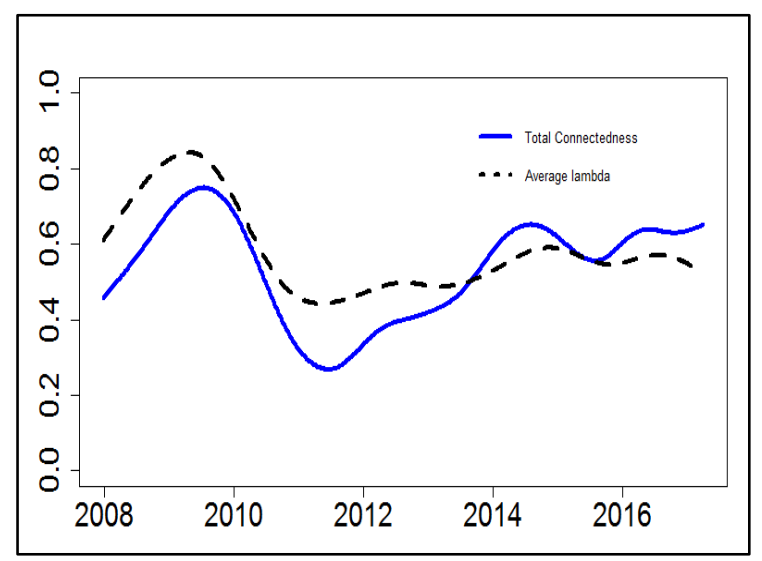

Notes: This figure shows the total connectedness and average Lambda of 31 Indian banks at 0.05 and 0.01 quantiles. 
Figure 3: TENET in Indian Banking Sector (Incoming and Outgoing links)

Panel A: Incoming links

TENET-IN [0.05 quantile]

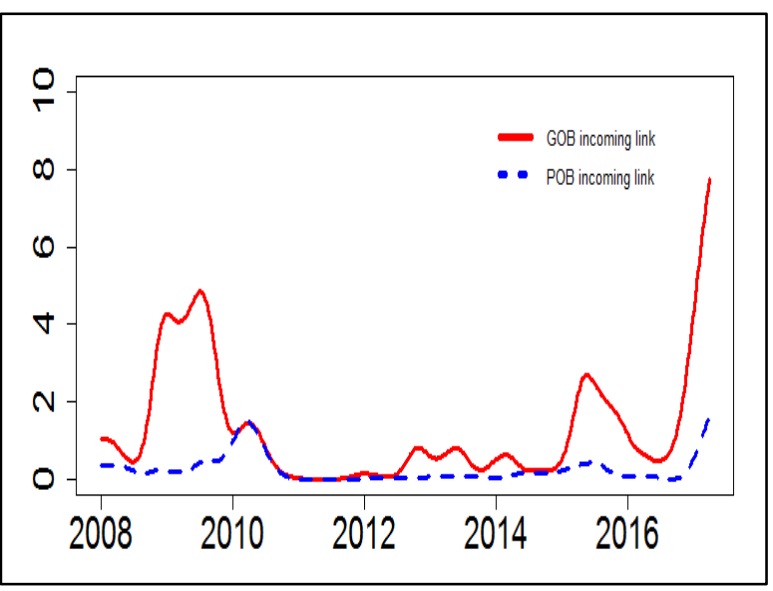

Panel B: Outgoing links

TENET-OUT [0.05 quantile]

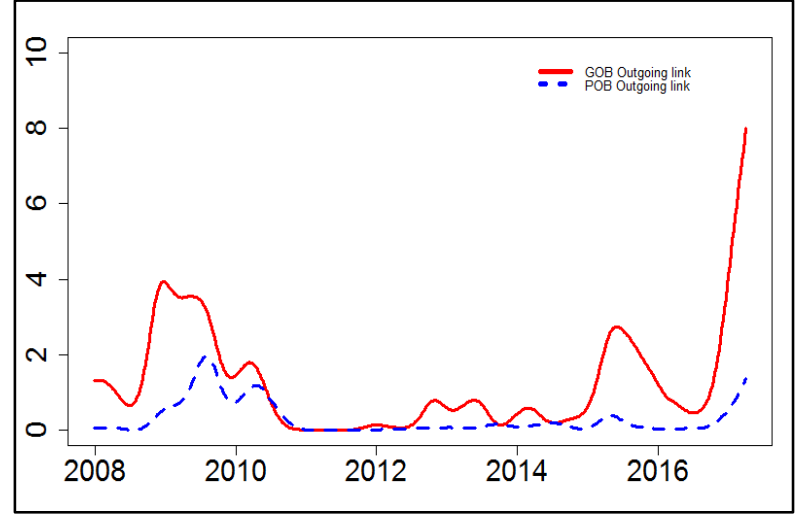

TENET-IN [0.01 quantile]

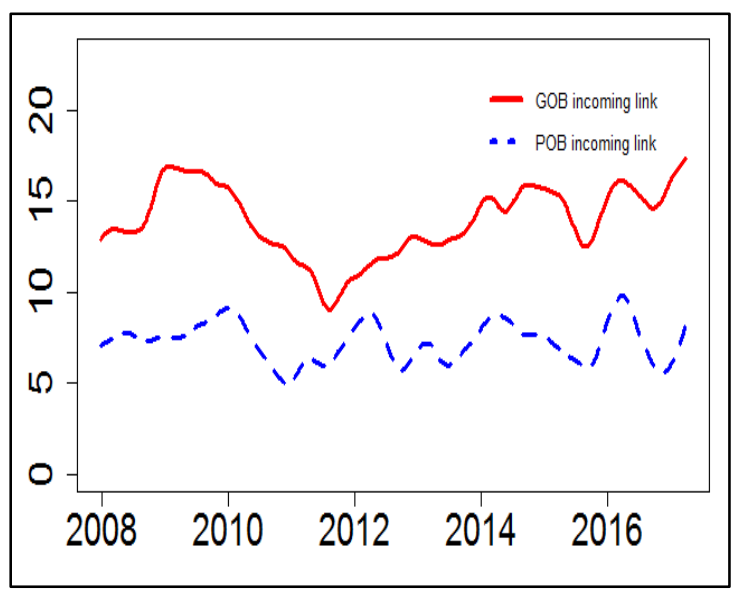

TENET-OUT [0.01 quantile]

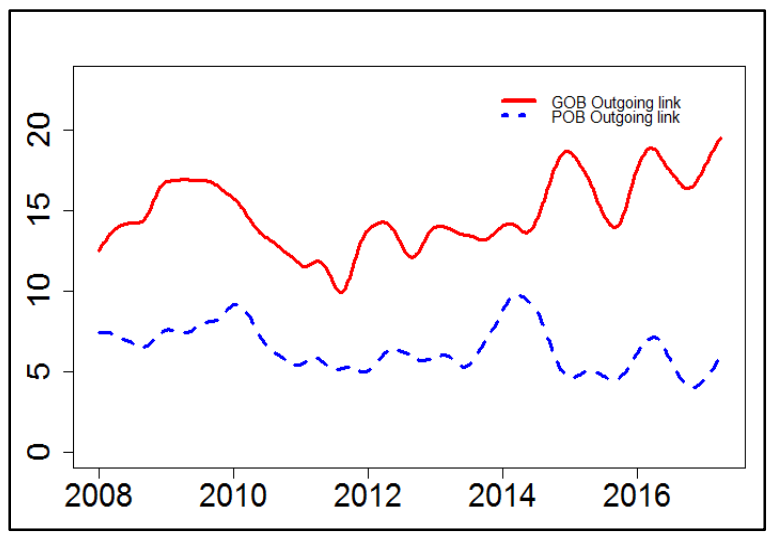

Note: GOB included 18 banks and POB included 13 banks. 
Figure 4: The tail-event driven network (TENET) of Indian banks

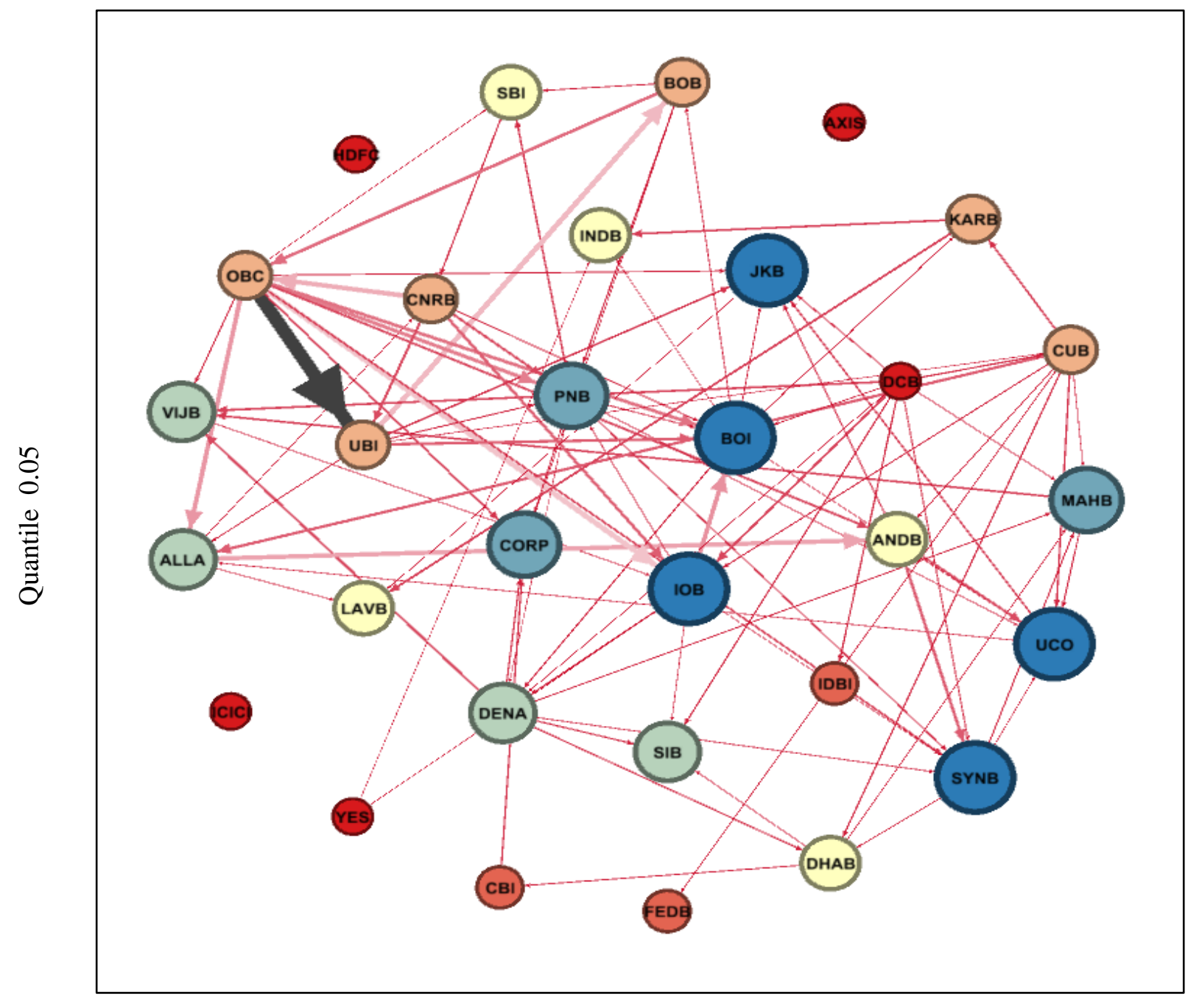




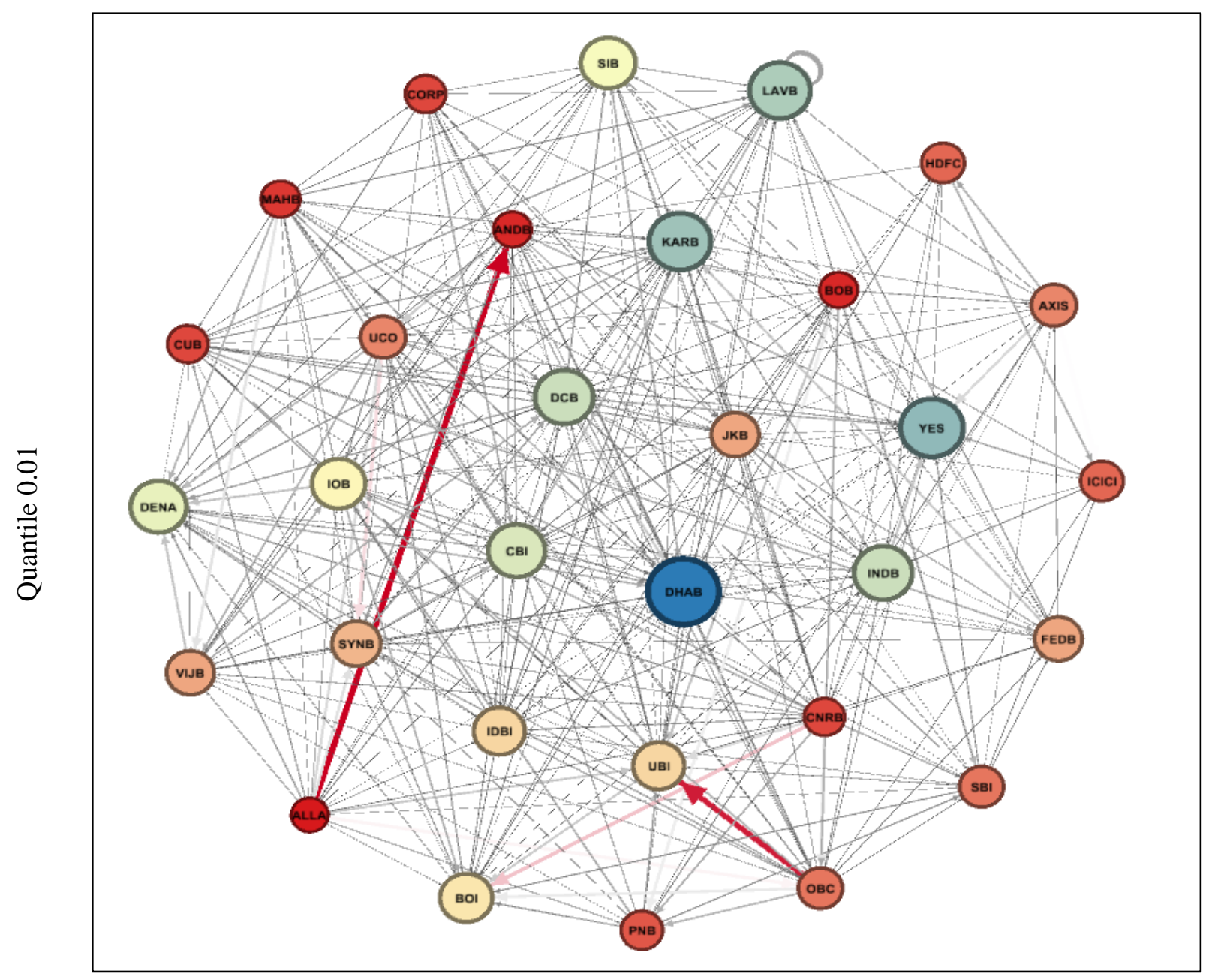

Note: To exhibit the interbank connectedness, we identify the anecdotal event date as 12 February 2016 when the stock market received the major jolt on the back of huge losses reported by major banks. 
Table 1: Descriptive statistics of Indian banks

\begin{tabular}{|c|c|c|c|c|c|c|c|c|}
\hline Banks & Abbr. & Mean & Max. & Min. & Std. Dev. & Kurtosis & Skewness & Obs. \\
\hline \multicolumn{9}{|l|}{ Government Banks (18) } \\
\hline Allahabad Bank & ALLA & -0.0003 & 0.2891 & -0.2529 & 0.0613 & 2.0796 & -0.1030 & 534 \\
\hline Andhra Bank & ANDB & -0.0008 & 0.2691 & -0.2555 & 0.0575 & 2.6483 & -0.0853 & 534 \\
\hline Bank Of Baroda & BOB & 0.0024 & 0.2141 & -0.2168 & 0.0578 & 1.5482 & -0.0404 & 534 \\
\hline Bank Of Maharashtra & MAHB & -0.0004 & 0.3450 & -0.1551 & 0.0506 & 5.1102 & 0.9561 & 534 \\
\hline Canara Bank & CNRB & 0.0002 & 0.2593 & -0.2009 & 0.0619 & 1.7523 & 0.2259 & 534 \\
\hline City Union Bank & CUB & 0.0047 & 0.4904 & -0.3010 & 0.0593 & 13.349 & 1.2908 & 534 \\
\hline Corporation Bank & CORP & -0.0005 & 0.2966 & -0.1841 & 0.0518 & 3.4480 & 0.6934 & 534 \\
\hline Oriental Bank of Commerce & $\mathrm{OBC}$ & -0.0009 & 0.2262 & -0.2485 & 0.0684 & 0.9536 & -0.0653 & 534 \\
\hline Punjab National Bank & PNB & 0.0007 & 0.2772 & -0.2514 & 0.0575 & 1.8081 & 0.1063 & 534 \\
\hline State Bank of India & SBI & 0.0017 & 0.2766 & -0.1978 & 0.0545 & 1.9230 & 0.3272 & 534 \\
\hline UCO Bank & $\mathrm{UCO}$ & 0.0009 & 0.3266 & -0.2455 & 0.0636 & 2.2695 & 0.0782 & 534 \\
\hline Vijaya Bank & VIJB & 0.0007 & 0.3218 & -0.2138 & 0.0573 & 3.1937 & 0.4050 & 534 \\
\hline Syndicate Bank & SYNB & -0.0001 & 0.2123 & -0.2318 & 0.0606 & 1.7908 & -0.2851 & 534 \\
\hline Union Bank of India & UBI & 0.0004 & 0.2296 & -0.2714 & 0.0654 & 1.5135 & 0.0014 & 534 \\
\hline IDBI Bank & IDBI & 0.0000 & 0.3586 & -0.2500 & 0.0647 & 2.7605 & 0.0596 & 534 \\
\hline Indian Overseas Bank & IOB & -0.0027 & 0.2449 & -0.2769 & 0.0597 & 2.2966 & -0.1491 & 534 \\
\hline Central Bank of India & CBI & 0.0001 & 0.3068 & -0.2490 & 0.0593 & 3.0750 & 0.0016 & 534 \\
\hline Bank of India & BOI & -0.0007 & 0.2641 & -0.2813 & 0.0671 & 2.1077 & -0.1076 & 534 \\
\hline \multicolumn{9}{|l|}{ Private Banks (13) } \\
\hline Axis Bank & AXIS & 0.0031 & 0.2303 & -0.2397 & 0.0584 & 1.1830 & -0.2808 & 534 \\
\hline DCB Bank & DCB & 0.0017 & 0.3696 & -0.3613 & 0.0721 & 3.5476 & -0.1386 & 534 \\
\hline Dena Bank & DENA & 0.0000 & 0.3076 & -0.2435 & 0.0624 & 2.4757 & 0.1205 & 534 \\
\hline Federal Bank & FEDB & 0.0032 & 0.1695 & -0.1911 & 0.0517 & 0.6953 & 0.0421 & 534 \\
\hline South Indian Bank & SIB & 0.0022 & 0.3231 & -0.1799 & 0.0514 & 3.9118 & 0.6358 & 534 \\
\hline HDFC Bank & HDFC & 0.0036 & 0.1766 & -0.1969 & 0.0416 & 2.6712 & -0.2639 & 534 \\
\hline ICICI Bank & ICICI & 0.0008 & 0.2566 & -0.3272 & 0.0608 & 3.3387 & -0.3375 & 534 \\
\hline IndusInd Bank & INDB & 0.0061 & 0.3438 & -0.2559 & 0.0609 & 3.9474 & 0.3686 & 534 \\
\hline Jammu \& Kashmir Bank & JKB & 0.0002 & 0.2700 & -0.2518 & 0.0547 & 3.8846 & 0.1652 & 534 \\
\hline Karnataka Bank & KARB & 0.0004 & 0.4410 & -0.2781 & 0.0612 & 5.4553 & 0.3595 & 534 \\
\hline Lakshmi Vilas Bank & LAVB & 0.0025 & 0.1962 & -0.2454 & 0.0521 & 1.4057 & 0.1640 & 534 \\
\hline Yes Bank & YES & 0.0045 & 0.2779 & -0.4915 & 0.0695 & 6.7093 & -0.7017 & 534 \\
\hline Dhanalaxmi Bank & DHAB & -0.0006 & 0.2900 & -0.3026 & 0.0706 & 2.3568 & 0.4861 & 534 \\
\hline
\end{tabular}

Notes: The study uses the weekly data of 18 government-owned and 13 privately-owned banks. The banks considered in our study are listed along with their abbreviations and the descriptive statistics for the returns of these banks over the sample period. The sample period: 12 January 2007 to 31 March 2017. 
Table 2: Systemic Risk Receiver (SRR)

\begin{tabular}{|c|l|l|l|c|l|l|l|}
\hline \multicolumn{4}{|c|}{ Panel A: 0.05 Quantile } & \multicolumn{4}{c|}{ Panel B: 0.01 Quantile } \\
\hline Rank & Banks & SRR & $\begin{array}{l}\text { Rank of MC } \\
\text { Value })\end{array}$ & Rank & Banks & SRR & $\begin{array}{l}\text { Rank of MC } \\
\text { Value })\end{array}$ \\
\hline 1 & SBI & $1.73 \mathrm{E}+16$ & $2(2339426203)$ & 1 & HDFC & $7.64 \mathrm{E}+17$ & $1(3696600324)$ \\
\hline 2 & HDFC & $1.51 \mathrm{E}+16$ & $1(3696600324)$ & 2 & ICICI & $7.06 \mathrm{E}+17$ & $3(1612506230)$ \\
\hline 3 & CNRB & $5.83 \mathrm{E}+15$ & $10(180829596)$ & 3 & AXIS & $5.87 \mathrm{E}+17$ & $4(1175483722)$ \\
\hline 4 & BOB & $3.99 \mathrm{E}+15$ & $7(398504402)$ & 4 & SBI & $4.63 \mathrm{E}+17$ & $2(2339426203)$ \\
\hline 5 & INDB & $3.46 \mathrm{E}+15$ & $5(852451627)$ & 5 & YES & $2.50 \mathrm{E}+17$ & $6(706069431)$ \\
\hline 6 & PNB & $2.65 \mathrm{E}+15$ & $8(318982442)$ & 6 & INDB & $2.38 \mathrm{E}+17$ & $5(852451627)$ \\
\hline 7 & AXIS & $1.22 \mathrm{E}+15$ & $4(1175483722)$ & 7 & BOB & $1.45 \mathrm{E}+17$ & $7(398504402)$ \\
\hline 8 & BOI & $1.12 \mathrm{E}+15$ & $13(146866293)$ & 8 & PNB & $5.83 \mathrm{E}+16$ & $8(318982442)$ \\
\hline 9 & UBI & $9.87 \mathrm{E}+14$ & $14(107172070)$ & 9 & CNRB & $4.20 \mathrm{E}+16$ & $10(180829596)$ \\
\hline 10 & IOB & $7.94 \mathrm{E}+14$ & $17(65418526)$ & 10 & BOI & $3.17 \mathrm{E}+16$ & $13(146866293)$ \\
\hline
\end{tabular}

Notes: This table provides the ranking of the top 10 Systemic Risk Receiver (SRR) banks. The size is decided by the magnitude of market capitalization. The list of top 10 Indian banks based on the index of Systemic Risk Receiver (SRR) at 0.05 quantile (Panel A) and 0.01 quantile (Panel B).

Table 3: Systemic Risk Emitter (SRE)

\begin{tabular}{|c|l|c|c|c|c|c|c|}
\hline \multicolumn{4}{|c|}{ Panel A: 0.05 Quantile } & \multicolumn{4}{c|}{ Panel B: 0.01 Quantile } \\
\hline Rank & Banks & \multicolumn{1}{|c|}{ SRE } & $\begin{array}{c}\text { Rank of MC } \\
\text { (Value) }\end{array}$ & Rank & Banks & SRE & $\begin{array}{c}\text { Rank of MC } \\
\text { (Value) }\end{array}$ \\
\hline 1 & PNB & $1.18 \mathrm{E}+16$ & $8(318982442)$ & 1 & HDFC & $\begin{array}{c}7.59 \mathrm{E}+1 \\
7\end{array}$ & $1(3696600324)$ \\
\hline 2 & YES & $8.94 \mathrm{E}+15$ & $6(706069431)$ & 2 & ICICI & $\begin{array}{c}7.44 \mathrm{E}+1 \\
7\end{array}$ & $3(1612506230)$ \\
\hline 3 & AXIS & $8.85 \mathrm{E}+15$ & $4(1175483722)$ & 3 & AXIS & $\begin{array}{c}5.47 \mathrm{E}+1 \\
7\end{array}$ & $4(1175483722)$ \\
\hline 4 & BOB & $7.94 \mathrm{E}+15$ & $7(398504402)$ & 4 & SBI & $\begin{array}{c}3.40 \mathrm{E}+1 \\
7\end{array}$ & $2(2339426203)$ \\
\hline 5 & SBI & $5.53 \mathrm{E}+15$ & $2(2339426203)$ & 5 & YES & $\begin{array}{c}3.25 \mathrm{E}+1 \\
7\end{array}$ & $6(706069431)$ \\
\hline 6 & UBI & $2.90 \mathrm{E}+15$ & $14(107172070)$ & 6 & INDB & $\begin{array}{c}1.82 \mathrm{E}+1 \\
7\end{array}$ & $5(852451627)$ \\
\hline 7 & OBC & $2.54 \mathrm{E}+15$ & $22(48758103)$ & 7 & BOB & $\begin{array}{c}1.26 \mathrm{E}+1 \\
7\end{array}$ & $7(398504402)$ \\
\hline 8 & ICICI & $2.25 \mathrm{E}+15$ & $3(1612506230)$ & 8 & PNB & $\begin{array}{c}1.04 \mathrm{E}+1 \\
7\end{array}$ & $8(318982442)$ \\
\hline 9 & BOI & $2.04 \mathrm{E}+15$ & $13(146866293)$ & 9 & CNRB & $\begin{array}{c}5.77 \mathrm{E}+1 \\
6\end{array}$ & $10(180829596)$ \\
\hline 10 & CNRB & $1.59 \mathrm{E}+15$ & $10(180829596)$ & 10 & CBI & $\begin{array}{c}4.65 \mathrm{E}+1 \\
6\end{array}$ & $9(200964362)$ \\
\hline
\end{tabular}


Notes: This table provides the ranking of the top 10 Systemic Risk Emitter (SRE) banks. The size is decided by the magnitude of market capitalization. The list of top 10 Indian banks based on the index of SRE at 0.05 quantile (Panel A) and 0.01 quantile (Panel B). 


\section{Appendix}

\section{Table A1: List of variables}

\begin{tabular}{|c|c|c|}
\hline Variable & Definition & Source \\
\hline Price Index & $\begin{array}{l}\text { Weekly closing stock price of bank: The price index expresses the price of an } \\
\text { equity as a percentage of its value on the base date, adjusted for capital } \\
\text { changes. }\end{array}$ & DataStream \\
\hline MC & $\begin{array}{l}\text { Market capitalisation of bank: Market price-year end multiplied with common } \\
\text { shares outstanding }\end{array}$ & DataStream \\
\hline MV & $\begin{array}{l}\text { Market value of bank: Market value on DataStream is the share price } \\
\text { multiplied by the number of ordinary shares in issue. } \\
\text { The amount in issue is updated whenever new tranches of stock are issued or } \\
\text { after a capital change. }\end{array}$ & DataStream \\
\hline BV & $\begin{array}{l}\text { Book value of bank: It represents the book value (proportioned common } \\
\text { equity divided by outstanding shares) at the company's fiscal year end. }\end{array}$ & DataStream \\
\hline Short-term debt & $\begin{array}{l}\text { Short-term debt of bank: It represents that portion of debt payable within one } \\
\text { year including current portion of long term debt and sinking fund } \\
\text { requirements of preferred stock or debentures. }\end{array}$ & DataStream \\
\hline Long-term debt & $\begin{array}{l}\text { Long-term debt of bank: It represents all interest bearing financial } \\
\text { obligations, excluding amounts due within one year. It is shown net of } \\
\text { premium or discount. }\end{array}$ & DataStream \\
\hline Total Loans & $\begin{array}{l}\text { Total loans of banks: Total loans represent the total amount of money loaned } \\
\text { to customers before reserves for loan losses but after unearned income. }\end{array}$ & DataStream \\
\hline Total Assets & $\begin{array}{l}\text { Total assets of banks: Total assets represent the sum of cash \& due from } \\
\text { banks, total investments, net loans, customer liability on acceptances (if } \\
\text { included in total assets), investment in unconsolidated subsidiaries, real estate } \\
\text { assets, net property, plant and equipment and other assets. }\end{array}$ & DataStream \\
\hline Total Debt & $\begin{array}{l}\text { Total debt of bank: All interest bearing and capitalized lease obligations. It is } \\
\text { the sum of long and short term debt. }\end{array}$ & DataStream \\
\hline Size & Log of total assets is used as proxy measure for the bank's size & DataStream \\
\hline MTB & Log of ratio of market value to book value of equity & DataStream \\
\hline Debt Maturity (DM) & Debt maturity is ratio of short-term debt to long-term debt & DataStream \\
\hline Leverage & Log of leverage, where leverage is ratio of total debt to market Value & DataStream \\
\hline ROA & Return on assets is defined as the ratio of total loans to total assets & DataStream \\
\hline MIBOR & Mumbai Interbank Offered Rate (MIBOR) & RBI \\
\hline T_bill 91 days & 3 months treasury bill rate & DataStream \\
\hline T_bill 10yr & 10 years bond rate & DataStream \\
\hline S\&P-BSE 30 Price index & S\&P BSE 30 Price index & \\
\hline Commercial Paper & Commercial paper by compound rate of interest average & DataStream \\
\hline STLS & $\begin{array}{l}\text { Short-term liquidity spread is difference between Mumbai Inter-bank Offered } \\
\text { Rate (MIBOR) and } 91 \text { days Treasury bill rate }\end{array}$ & ---- \\
\hline Change in T_bill 91 days & Change in the 3 months Treasury bill rate & ---- \\
\hline T_bill 10yr - T_bill 3 months & $\begin{array}{l}\text { Difference Between } 10 \text { years Treasury bill rate and } 3 \text { months Treasury bill } \\
\text { rate }\end{array}$ & ---- \\
\hline Credit Spread & $\begin{array}{l}\text { Credit spread is the difference between commercial paper and } 3 \text { months } \\
\text { treasury bill rate }\end{array}$ & ---- \\
\hline Weekly Market Returns & Weekly market returns is defined as log return of S\&P BSE 30 price index & ---- \\
\hline Market Volatility & $\begin{array}{l}\text { Log of market volatility is defined as conditional variances of BSE } 30 \text { index } \\
\text { using GARCH }(1,1)\end{array}$ & ---- \\
\hline Lending Rate & Prime lending rate of bank & RBI \\
\hline
\end{tabular}

Note: RBI stands for Reserve Bank of India. 
Table A2: Total directional connectedness ("FROM")

\begin{tabular}{|c|l|c|l|c|l|l|c|}
\hline \multicolumn{4}{|c|}{ Panel A: 0.05 Quantile } & \multicolumn{4}{c|}{ Panel B: 0.01 Quantile } \\
\hline Rank & Banks & IN-Sum & $\begin{array}{l}\text { Rank of MC } \\
\text { (Value) }\end{array}$ & Rank & Banks & IN-Sum & $\begin{array}{l}\text { Rank of MC } \\
\text { (Value) }\end{array}$ \\
\hline 1 & UBI & 48.61 & $14(107172070)$ & 1 & DCB & 450.22 & $23(48583281)$ \\
\hline 2 & IOB & 47.66 & $17(65418526)$ & 2 & DHAB & 418.15 & $31(6242937)$ \\
\hline 3 & OBC & 46.62 & $22(48758103)$ & 3 & JKB & 413.88 & $27(39099980)$ \\
\hline 4 & ALLA & 46.44 & $21(54624020)$ & 4 & CBI & 400.26 & $9(200964362)$ \\
\hline 5 & CNRB & 43.24 & $10(180829596)$ & 5 & UCO & 397.03 & $20(56384173)$ \\
\hline 6 & BOB & 38.25 & $7(398504402)$ & 6 & DENA & 374.89 & $30(30147841)$ \\
\hline 7 & BOI & 37.12 & $13(146866293)$ & 7 & OBC & 373.15 & $22(48758103)$ \\
\hline 8 & JKB & 35.26 & $27(39099980)$ & 8 & UBI & 372.48 & $14(107172070)$ \\
\hline 9 & ANDB & 35.09 & $25(39473424)$ & 9 & IOB & 371.49 & $17(65418526)$ \\
\hline 10 & SYNB & 34.18 & $18(64448435)$ & 10 & CNRB & 368.38 & $10(180829596)$ \\
\hline
\end{tabular}

Notes: This table shows the total connectedness of top 10 banks. The ranks are decided based on the magnitude of total connectedness ("Only From") estimated using Härdle et al. (2016) model at the quantiles of 0.05 (Panel A) and 0.01 (Panel B).

Table A3: Total directional connectedness ("TO")

\begin{tabular}{|c|l|c|c|c|l|l|c|}
\hline \multicolumn{4}{|c|}{ Panel A: 0.05 Quantile } & \multicolumn{4}{c|}{ Panel B: 0.01 Quantile } \\
\hline Rank & Banks & IN-Sum & $\begin{array}{l}\text { Rank of MC } \\
\text { (Value) }\end{array}$ & Rank & Banks & IN-Sum & $\begin{array}{l}\text { Rank of MC } \\
\text { (Value) }\end{array}$ \\
\hline 1 & OBC & 152.8 & $22(48758103)$ & 1 & OBC & 636.97 & $22(48758103)$ \\
\hline 2 & UBI & 79.44 & $14(107172070)$ & 2 & UBI & 498.58 & $14(107172070)$ \\
\hline 3 & DCB & 55.51 & $23(48583281)$ & 3 & ALLA & 486.9 & $21(54624020)$ \\
\hline 4 & IOB & 41.47 & $17(65418526)$ & 4 & CNRB & 464.9 & $10(180829596)$ \\
\hline 5 & CUB & 41.12 & $15(91121435)$ & 5 & ANDB & 433.99 & $25(39473424)$ \\
\hline 6 & BOI & 38.45 & $13(146866293)$ & 6 & UCO & 430.74 & $20(56384173)$ \\
\hline 7 & PNB & 38.13 & $8(318982442)$ & 7 & DENA & 428.23 & $30(30147841)$ \\
\hline 8 & DENA & 33.4 & $30(30147841)$ & 8 & BOI & 400.77 & $13(146866293)$ \\
\hline 9 & ANDB & 29.3 & $25(39473424)$ & 9 & SYNB & 394.31 & $18(64448435)$ \\
\hline 10 & CNRB & 26.56 & $10(180829596)$ & 10 & CBI & 393.85 & $9(200964362)$ \\
\hline
\end{tabular}

Notes: This table shows the total connectedness of top 10 banks. The ranks are decided based on the magnitude of total connectedness ("Only To") at the quantiles of 0.05 (Panel A) and 0.01 (Panel B). 
Click here to download Data in Brief: Data_EL.rar

Data in Brief Click here to download Data in Brief: Data_EL.rar

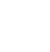

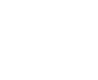

$\sqrt{2}$

$\sqrt{2}$

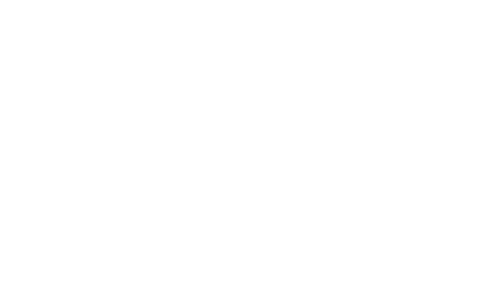

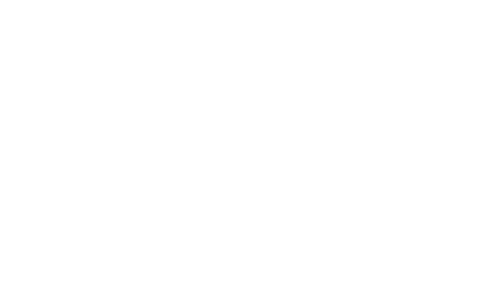

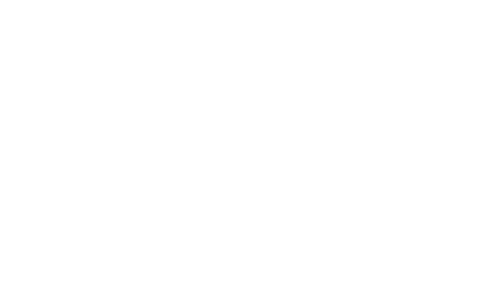

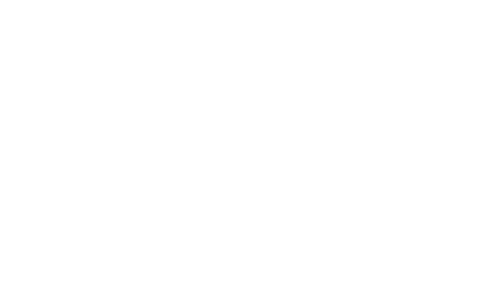

(n)

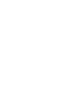

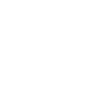

(1)

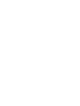

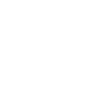

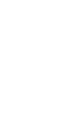

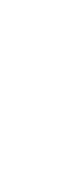

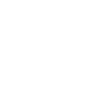

